Muscles, Reflexes, and Locomotion 

Thomas A. McMahon

\section{Muscles, Reflexes, and Locomotion}

Princeton University Press

Princeton, New Jersey 
Published by Princeton University Press, 41 William Street, Princeton, New Jersey In the United Kingdom: Princeton University Press, Chichester, West Sussex

All Rights Reserved

\section{Library of Congress Cataloging in Publication Data}

McMahon, Thomas A., 1943-

Muscles, reflex, and locomotion.

Bibliography: $p$.

Includes index.

1 . Muscle contraction--Mathematical models.

2. Reflexes-Mathematical models. 3. Animal locomotion-Mathematical models. I. Title. [DNLM:

1. Muscles-Physiology. 2. Reflex--Physiology.

3. Movement. 4. Locomotion. WE $500 \mathrm{M} 478 \mathrm{~m}]$

QP321.M338 $1984 \quad 591.1^{\prime} 852 \quad 82-23156$

ISBN 0-691-08322-3

ISBN 0-691-02376-X (pbk.)

This book has been composed in Times Roman

Princeton University Press books are printed on acid-free paper, and meet the guidelines for permanence and durability of the Committee on Production Guidelines for Book Longevity of the Council on Library Resources

Printed in the United States of America

$\begin{array}{llllll}9 & 8 & 7 & 6 & 5 & 4\end{array}$ 